\title{
Ciência e Educação em um mundo de impermanência entrevista com Áttico Chassot
}

por Silvia Nogueira Chaves e convidados

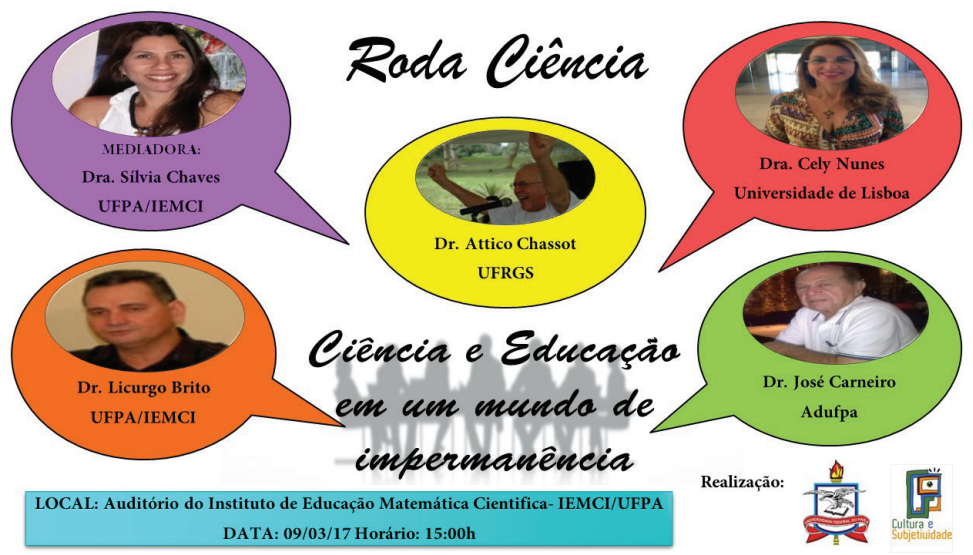

Tnaugurando o "Roda Ciência", atividade organizada pelo GEPECS Lcom inspiração no programa "Roda Viva" da TV Cultura, tivemos, em 9 de março de 2017 a presença honrosa do querido e ilustre professor Áttico Chassot, que debateu o tema Ciência e Educação em um mundo de impermanência ${ }^{1}$. Químico, graduado pela Universidade Federal do Rio Grande do Sul, com doutorado pela mesma instituição. Já dedicou 56 dos seus 77 anos, a pesquisa e à docência. Nascido em Estação Jacuí, Rio Grande do Sul, atualmente é professor-pesquisador e orientador de doutorado na Rede Amazônica

1 Transcrição Geórgia de Souza Tavares. Revisão técnica: Silvia Nogueira Chaves e Carlos Aldemir Farias da Silva. 
de Educação em Ciências e Matemática (REAMEC), um programa de doutorado implementado por uma Associação em rede de Instituições de Ensino Superior da Amazônia Legal Brasileira. Com vários livros publicados, dentre eles se destacam: A ciência através dos tempos; Para quem é útil o ensino?; Alfabetização científica: questões e desafios para a educação e A ciência é masculina? É sim senhora. Ele também vem se consagrando como um dos mais brilhantes autores brasileiros da área do Ensino e da Educação em Ciências, História e Filosofia da Ciência. Conectado ao mundo virtual mantém, há 8,5 anos, um blog (http://mestrechassot.blogspot.com.br) no qual além de difundir conhecimentos científicos brinda-nos com ensaios sobre ciência, política, religião e demais temáticas pulsantes no país e no mundo, sempre em uma abordagem contemporânea. Tem sido convidado como palestrante em todos os estados brasileiros e em alguns países.

Para entrevistá-lo convidamos os não menos queridos e ilustres colegas Cely Nunes, José Carneiro e Licurgo Brito. Além desses, o Roda Ciência contou com a participação do público presente, formado por estudantes de graduação e pós-graduação, técnicos e docentes de vários institutos da Universidade Federal do Pará (UFPA), que lotou as dependências do auditório do Instituto de Educação Matemática e Científica (IEMCI). Coube a mim, Sílvia Nogueira Chaves, a honra de coordenar o debate.

Silvia: Professor Chassot, hoje vamos discutir sobre impermanência, sobre como ficam a ciência e a educação nesse mundo de impermanência. Homem e ciência nasceram juntos, o humano e a ciência, nasceram no século XVI com a modernidade. A educação veio em seguida como projeto de iluminação desse homem. $\mathrm{O}$ projeto iluminista previa que a ciência, o conhecimento científico, iria mitigar a fome, acabar com a barbárie, e nada disso aconteceu. 
Vivemos ainda hoje num mundo de barbárie, há, ainda, muita fome no mundo. Para alguns autores a ciência ainda não cumpriu suas promessas, seu projeto de modernidade, não iluminou suficientemente o humano, o mundo e a sociedade. Vivemos no presente conflitos de toda ordem, há reinvindicações identitárias específicas que desafiam a educação. Hoje vivemos um mundo de pulverizações identitárias. Se na modernidade nos tínhamos um humano único, universal, hoje temos pluralidade de identidades (étnicas, sexuais ...). Vivemos em um mundo de aceleração do tempo e também da tecnologia. Em algumas obras e palestras o senhor já comentou que objetos e algumas profissões e práticas foram extintas ao longo do tempo e outras vieram tomar o lugar. Hoje vivemos em um mundo que nada foi feito para durar. Como pensar a educação, a ciência e a educação em ciências, num mundo movente e de impermanências?

Chassot: Em primeiro lugar, não sei se faz parte do ritual, mas vou feri-lo se não fizer, quero agradecer a oportunidade de estar aqui mais uma vez na Amazônia, mais uma vez no Pará e mais uma vez na UFPA, nesse campus lindo do Guamá. É muito bom estar aqui, eu gosto de estar aqui e obrigado por me trazer e por provocar esse friozinho que todos os marços sinto no começo do ano letivo. $\mathrm{Na}$ próxima segunda-feira vou fazer 56 anos de professor, então acho que vale a pena viver essa emoção com vocês agora. Sobre a pergunta da Sílvia, a análise muito bem-posta da Sílvia, podia-se dizer que ela fez apenas do ocidente. Toda essa análise que foi feita é do ocidente. E a pergunta que toda hora nos fazemos: por que no oriente não houve revolução científica? Ou melhor, ainda, por que houve revolução científica no ocidente? Essa é a grande pergunta que talvez devêssemos responder. E talvez por causa disso, porque na minha hipótese nós fizemos revolução científica, porque 
as três grandes religiões abraâmicas que comandam o ocidente: o judaísmo, o cristianismo e o islamismo, são por demais ortodoxas, por demais rígidas. E ensinaram as ciências a serem rígidas e ortodoxas e como consequência disso a ciência não está dando conta do recado. Mesmo que nos maravilhemos, vendo fazer surgir e desaparecer profissões, mesmo que haja essa fugacidade, essa ligeireza, ou melhor essa rápida ação, não estamos cumprindo o calendário, não estamos fazendo o que devíamos fazer. Acho que a pergunta da Sílvia para mim é a pergunta para cada uma e cada um de nós que vive esses impactos, deste chamado "doente século XXI". Por exemplo, aqui no Brasil vivemos sobre a égide de uma ditadura, de um governo ilegítimo, o mundo se assombra com o presidente da nação mais poderosa do mundo, que tem em suas mãos um arsenal atômico que se ele resolver brincar, sabemos o que ele pode fazer. Vemos cidades que antes eram ditas seguras, como minha cidade Porto Alegre, hoje é uma das cidades mais violentas e trágicas do país. Por que que está acontecendo tudo isso? Mas a Sílvia trouxe uma segunda colocação, um binômio, quando ela fala Ciência e Educação, e nos vemos o quanto a educação, que nos faz mais poderosos, está sendo radicalmente mal-usada. Eu não quero ser um profeta do apocalipse (eu sou um otimista, eu acho que nós podemos dar conta de virar isso, vamos conseguir virar), mas essa é uma coisa que nós interrogamos: para onde é que vai a nossa educação científica? $\mathrm{O}$ que estamos fazendo com ela? E não é sem razão que estamos neste instituto que tem como característica fazer uma educação científica e matemática. Eu acho que é isso que estamos pensando, como é que vamos chegar lá, me ajudem os colegas da roda, como podemos chegar lá?

Cely: Boa tarde a todos, especialmente ao professor Chassot. Ouvindo sua fala, eu recordei dos momentos que eu estive aqui, 
ainda quando esta casa se chamava NPADC (atual Instituto de Educação Matemática e Científica), em que eu vinha muito motivada a ouvi-lo, a aprender com o senhor. Relendo alguns de seus livros me veio uma curiosidade, eu gostaria de ouvi-lo um pouco mais, sobre o seu processo de alfabetização científica, o que mais lhe despertou em termos formativos? Foram os professores do ensino básico, os professores do ensino secundário, do ensino superior, de mestrado, doutoramento, estamos nesse permanente estado de nos educar para a ciência. E nesse processo da sua educação científica o que mais lhe tem chamado atenção em termos formativos?

Chassot: Hoje de manhã, num minicurso que estou ministrando aqui na UFPA, eu dizia do encantamento que tenho pelas pessoas (que são geralmente mulheres, há homens também) alfabetizadoras. Eu acho que essa magia que faz os humanos distinguidos, no sentido de converter esse binômio escrita-leitura, é algo fantástico. Aqueles que acompanham filhos, e eu agora já tenho o privilégio de acompanhar netos, aprendendo a ler, eu acho que isso é a coisa mais bonita que tem, eu diria quase mais mágica. $\mathrm{E}$ agora na alfabetização científica, que tu me perguntas. Ver, não necessariamente uma criança, uma pessoa qualquer progredindo, ir entendendo, por exemplo, como é que ela aprende, como é que ela sabe, como é que ela pode abrir uma tampa metálica que fecha o vidro de uma conserva? Como é que ela descobre? Como é que ela pode fazer? Como é que ela faz para descascar cebola sem chorar? Ou como é que ela sabe que plantando determinadas plantas não apenas elas embelezam, mas não vai vir mosquitos. Como é que esses saberes primitivos foram construídos pelos homens e pelas mulheres ao longo dos tempos? Nós ouvimos ainda na palestra de ontem à noite, aqueles que estiveram nesse seminário do qual participo, como é que as benzedeiras, como é que as avós curavam ou 
curam. Isso para mim também é alfabetização científica. E talvez seja isso que mais me encanta, e pode ser a descoberta de um aluno da educação infantil, ou pode ser um doutorando, um doutor em física fazendo essas descobertas e sabendo explicar. Eu sempre imagino, e eu remonto muito ao meu passado, olhando, por exemplo, o que significaria para a minha avó, chegar e apertar num botão e acender as luzes elétricas. Ou que fantásticas são essas torneiras dos banheiros do shopping, que tu aproximas a mão e ela já jorra água, quando minha avó tinha que pegar um balde e buscar longe água na cacimba e agora é só tocar... Como é que explicamos? É uma mágica? Como é que funciona isso? Ou como é que um trovão que servia antes para criar um Deus e como é que agora a física explica um trovão? Eu acho que estes são os aprendizados do nosso dia a dia. A ciência é uma linguagem feita pelos homens e pelas mulheres, e aí vem a serventia (é outra palavra muito bonita), isso tem serventia! Para quê que serve a ciência, para explicar o mundo natural. Então, eu respondo a tua pergunta todas as coisas que me motivam nessa alfabetização científica é conseguir responder a essas coisas tão simples, e por isso que muitas vezes ensinamos coisas complicadas, por que essas temos as regras. Mas, não sabemos responder as coisas mais simples do cotidiano de uma cozinha, do cotidiano de uma lavadeira, do cotidiano de uma benzedeira. Eu acho que é isso que me encanta, conseguir explicar esses saberes primeiros, e esses saberes primeiros fazer deles saberes escolares.

Carneiro: Boa tarde a todos e a todas. Inicialmente quero registrar meu prazer de estar aqui. Me sinto um pouco um peixe fora d'água por que eu tenho me dedicado muito à memorialística, e estou num ambiente científico, um pouquinho fora d'água. Mas, com a liberdade de fazer ao professor Chassot qualquer pergunta, eu me ative ao livro de memória dele, "Memória de um professor", 
no qual em 500 páginas ele conta quase nada da vida dele, de tão profícua que ela é que não cabe em 500 páginas. Professor Chassot, quando foi lançado a biografia de Euclides da Cunha, foi uma publicação do Roberto Ventura, eu fiz um artigo a respeito e intitulei: "O polímata atormentado", talvez no seu caso impaciente coubesse melhor. Um polímata que depois de 55 anos de magistério, virou além de polímata um peregrino da ciência, que eu também denominei num artigo que escrevi sobre você. Por que você circula agora no país inteiro disseminando seus conhecimentos científicos. Então, vai a minha pergunta em cima do seu livro de memória. Eu acho professor Chassot, que nessas 500 páginas você tentou fazer um acerto de contas com a sua instigante história. Esse acerto de contas lhe deixou satisfeito com o resultado? Seja de críticas, ou seja, de afago ao seu ego?

Chassot: Foi decepcionante. O livro esgotou e a editora pediu para reimprimir e eu disse que não queria reimprimir o livro. Tenho mais arrependimentos do que alegrias de ter feito esse livro. Mas, primeiro eu queria fazer uma correção ao Carneiro. Ele disse "memorialista e que está no meio da ciência”, como se fazer memória não fosse um trabalho científico também Carneiro, então sinta-se à vontade entre nós, aqui tu não és um peixe fora d'água.

Carneiro: Mas eu perguntei só para responder sim ou não. Por que você não gostou do livro? (Risos).

Chassot: Eu não gostei no livro, primeiro porque eu disse coisas que eu não precisava ter dito. Me arrependo por tê-las dito. Segunda coisa eu não gostei do livro porque não teve o sucesso que deveria ter tido. Isso o meu ego foi ferido (risos).

Licurgo: Bom, também é claro que embora sendo repetitivo, não dá para pular a parte da enorme satisfação de estar aqui com 
o professor Chassot em particular, com quem eu já tive oportunidade de partilhar mesas-redondas em outros momentos, é sempre um prazer. Mas, também, lhe assisto nos vídeos do YouTube e outros canais além dos seus livros e artigos. Quero parabenizar a professora Sílvia pelo evento e pela escolha desses colegas tão instigantes. Professora Cely, a muito tempo não a via, e o professor Carneiro que agora estou podendo falar. Professor Chassot, gostaria de retomar o tema da impermanência que a professora Sílvia trouxe e o senhor colocou muito bem, a pergunta que ela fez pode ter muitas respostas e talvez algumas delas sejam tangenciadas durante a nossa conversa. E para tangenciar algumas delas, eu quero lembrar que estamos num momento no plano educacional, eu acho que no mundo inteiro, mas em particular aqui no Brasil e no Pará, vivenciando mudança muito forte nas crenças que temos a respeito dos processos de ensino, particularmente do ensino de ciências. A forma clássica de ensinar, que existia como única nos momentos que eu iniciei o magistério e, provavelmente, o senhor também, já se vê dentro da academia como algo um pouco mais distanciado, já não é mais a hegemonia dentro dos ambientes de pesquisa em educação em ciências, já não se pensa mais naquela mesma forma, e aos poucos esse pensamento da academia vai querendo se infiltrar nas escolas, vai querendo se fazer presente nos procedimentos de ensino. Temos, então, uma impermanência. Mas, a questão sobre essa situação é a seguinte: nesse afã de mudanças temos muitas ideias que surgem nas quais nós pesquisadores e professores nos apoiamos. Uma delas veio, a alfabetização científica, outra, letramento, ensino de ciências com enfoque ciência, tecnologia e sociedade, e tantas outras. A questão é: isso é uma provisoriedade, com a sua vivência, com a sua história, ou já se pode dizer que isso já são indícios de alguma permanência que eu mesmo ainda não consegui identificar? 
Chassot: Acho que somos naturalmente conservadores. Fico muito mal quando eu me reconheço conservador. Vou dar um exemplo. Há um ano atrás decidi não mais assinar jornal em suporte de papel, passei a assinar jornal em suporte eletrônico. Vou dizer com tristeza que estou com vontade de voltar a assinar o jornal em suporte de papel, porque eu não sei o que piorou, mas não tem graça nenhuma em ler um jornal num tablet do que em suporte de papel, é completamente diferente. Talvez porque eu seja viciado em livro, papel, essas coisas, mas eu sinto falta de ter o jornal onde eu podia riscar, marcar, chamar atenção. Vocês vão dizer que tudo isso não dá para fazer no eletrônico, mas não é a mesma coisa. Eu sou, dos vícios que eu tenho, um é fazer Sudoku. Fazer Sudoku em suporte eletrônico não tem graça nenhuma, tem que fazer com uma caneta e fazer direto para não poder apagar etc. Então, vamos olhar só essa coisa do suporte de leitura. Realmente estamos experimentando coisas novas na educação, mas a meu juízo as experimentamos muito devagar. Não somos contaminados pela rapidez, talvez seja isso o necessário. Agora o que eu vejo de mais trágico que está se fazendo na educação é quando nós professores e professoras que estudamos para isso estamos perdendo nosso lugar, chamando aqueles que foram bem-sucedidos no mercado, por exemplo, de vender cerveja, ou aqueles que foram bem-sucedidos no mercado disso ou daquilo, e eles agora querem dizer como é que tem que ser a educação, essa é a grande coisa. Eles não nos perguntam, aliás, nós não sabemos dizer para eles como vender cerveja, mas eles sabem fazer educação, quer dizer, essa coisa fantástica, da maneira como vamos perdendo nossos lugares de educadores, porque todo mundo sabe fazer educação. Essa eu acho que é a dificuldade maior hoje. Quem é que tem que fazer educação nesse país e nesse mundo? 
Silvia: Farei uma primeira pergunta da plateia. O Professor Chassot acabou de mencionar os projetos pós Sputnik que vinham com a intenção de revolucionar o ensino de ciências no mundo. No Brasil também chegaram mesmo que precariamente. Tem uma pergunta que vai nessa direção aqui da plateia: o que foi produzido em termos de ensino de ciências no projeto Nuffield em que você participou nos anos 1960?

Chassot: Em primeiro lugar uma correção, eu não participei do projeto Nuffield, eu vi, ajudei a trabalhar, mas, evidentemente eu não participei. Bom, vamos dividir os projetos em consequência do Sputnik, o estadunidense foram o de física, o de matemática, de biologia... o BSCS (Biological Science Curriculum Studies), o PSSC (Physical Science Study Commitee), o CBA (Chemical Bond Approach), o CHEM (Chemical Education Material Study)..., a gente chamava o coquetel de letras. E houve um deles, o britânico. O britânico Nuffield. Qual era a diferença do Nuffield desses outros projetos? Primeiro eu acho que o Nuffield era menos experimentador, lembro, quem trabalhou com esses projetos, eu não sei se alguns se lembram, mas começava com a experiência da vela, apaga a vela, e produz a chama ${ }^{2}$, e depois aquela experiência da caixa, botava o objeto dentro da caixa e tinha que adivinhar o que tinha dentro da caixa, etc. E o Nuffield era mais conceitual, o Nuffield trabalhou muito com conceitos. Quer dizer, a diferença fundamental, uns estadunidenses e outros Nuffield, ingleses é que os Estados Unidos divulgaram muito mais os projetos deles. Todos os países, era a época, se não me engano, da Aliança

2 Há inúmeras descrições sobre tal experiência na internet, dentre elas a divulgada em http://www.cienciamao.usp.br/tudo/exibir.php? midia=rip\& $\operatorname{cod}=$ experienciadavela4-termologia-txttem0017 (Esta e todas as demais notas são de autoria de Silvia Chaves). 
para o Progresso, e aí então isso foi traduzido por todo o país. Foi muito mal traduzido, aqui no Nordeste tinham coisas bárbaras assim, no Norte ou no Nordeste, por exemplo: "vá ao pátio e pegue um pouco de neve para fazer uma experiência", quer dizer, nunca vimos neve e éramos chamados a ir pegar neve no pátio, traduções equivocadas. Mas eles tiveram coisas boas, eu acho que no Brasil o trabalho da FUNBEC (Fundação Brasileira para o Desenvolvimento de Ensino de Ciências), mais precisamente do Isaias $\mathrm{Raw}^{3}$ foi um grande disseminador desses projetos. Eu me lembro que o Isaias Raw viajava o Brasil inteiro, e depois, se não me engano a Brasil Cultural vendia caixinhas de isopor onde se podia montar microscópios e outras coisas mais. Eu acho que talvez foi um período do auge de divulgação, foi a época dos centros de ciências no Brasil inteiro, quer dizer, teve essa consequência eu acho que boa, se trabalhou em formar professores de ciências. Agora o Nuffield tem essa diferença então, que ele era menos estadunidense e mais inglês, e, portanto, menos daquela coisa de colonização. Os projetos tinham a marca da colonização, "vamos fazer como nós fazemos!".

Licurgo: Só para provocar um pouco mais, e talvez esclarecer a plateia mais jovem, de fato professor, eu vivi na adolescência a efervescência desses modelos, a coleção, as caixinhas (kits de experimentação) que foram feitas no Brasil dos chamados, da FUNBEC, elas circulavam entre nós adolescentes como hoje circulam os games da internet...

3 Médico graduado pela USP. Pesquisador do Instituto Butantã, no qual foi também diretor. Pioneiro no desenvolvimento da área de ensino de Ciências no Brasil, criando à frente da FUNBEC o uso de kits que permitiu estudantes realizarem experimentos em casa, culminando com a série Cientistas, que levou à utilização de kits experimentais. Atualmente é pesquisador aposentado da Universidade de São Paulo. 
Chassot: Os Pokémons...

Licurgo: Os Pokémons, e aquilo era uma febre. O garoto que nunca tinha brincado com uma caixinha de pequeno cientista estava fora da comunidade, ele era um estranho, e eu me sentia esse estranho, porque eu não tinha a caixinha, mas então eu ia para casa dos primos e dos colegas de escola que tinham para poder brincar. Nós marcávamos horário no contra turno para ir à casa de colegas para brincar de cientista. Então, isso não pode ter sido nada. Eu acho que isso foi um efeito desses projetos aqui do Brasil que se fizeram, embora com um certo tom de cópia, com as adaptações necessárias e se tornaram acessíveis à nós.

Chassot: Confere. E eu acho que está certo e o Instituto Brasileiro de Educação, Cultura e Ciências (IBECC) nesse ponto fez um trabalho. Tinha uma premiação de "cientistas do amanhã”, da professora Julieta Ormastroni ${ }^{4}$, se não me engano, era um sucesso. Eu esperava na banca o dia de chegar a caixinha, etc. Ninguém desses jovens conheceu nem coisa parecida, quer dizer, não vou dizer agora que eles não cacem Pokémon..., mas com o que hoje a gente vê os netos da gente brincar é impressionante, se comparado com isso (os kits).

Cely: Professor, ainda na esteira das comemorações do dia da mulher, que foi ontem (essa comemoração internacional, pelo menos no plano ocidental, embora eu defenda que o dia da mulher e do homem são todos os dias), eu pergunto para o senhor

4 Maria Julieta Sebastiani Ormastroni foi diretora do Instituto Brasileiro de Educação, Ciência e Cultura (IBECC), ligado à UNESCO, participou da criação - a partir de ideia de seu amigo José Reis - do Concurso Cientistas de Amanhã, atuou na promoção de feiras de ciências, conduziu atividades científicas com crianças para a Folhinha, suplemento infantil do jornal Folha de São Paulo. 
se a ciência ainda continua masculina. E o que se pode ainda argumentar a esse respeito do presente momento? A respeito da porção mulher que existe nesta tão dita ciência masculina, se é que existe essa porção mulher...

Chassot: Duas coisas, primeiro a respeito do dia de ontem. Eu caprichei, eu fiz um blog sobre as mulheres da minha vida, quem não leu vale a pena, tema para casa. Segunda coisa, "a ciência continua masculina(?)". Professora, lamentavelmente, se usarmos um dos indicadores que eu uso no meu livro - eu uso dois indicadores, um são os prêmios nobeis e outro é aquela lista da pesquisa do Michel Ray, que está publicada no livro "The one hundred" - ela continua masculina. Vou pegar os prêmios nobeis do ano passado. Química, 3 homens; física, 2 homens; literatura, 1 homem; medicina e fisiologia, 3 homens; paz, 1 homem; economia, 1 homem. Não teve mulher no ano de 2016. Ano retrasado, 2015, também não teve representação feminina. Quer dizer, então, hoje são menos de $3 \%$ as mulheres que ganharam os prêmios nobeis. 17 em 353. Isso tudo eu não tenho exato, mas é em torno disso. Dessas 17 mulheres que ganharam apenas 3, a filosofia, as artes e a política, e quando uma mulher se destaca na política olha o que nós fizemos, nós tiramos ela (referência ao Impeachment da ex-presidente do Brasil, Dilma Rousseff) talvez também por ser mulher. Nas religiões, a grande esperança era que o Papa Francisco iria falar no sacerdócio feminino. Podemos tirar o cavalinho da chuva, isso não vai acontecer com esse papa. Se esperava que Bento XVI convocasse o concílio vaticano III, não convocou e provavelmente... o papa argentino pode até ser bom, mas a cúpula romana está bloqueando, impedindo esse papa de fazer coisas melhores. Talvez o documento mais importante desse papa seja a encíclica de junho 
de $2015^{5}$, e que foi criticado, principalmente pelas grandes produtoras de carvão mineral. Quer dizer, é muito complicado, somos conservadores, então a ciência continua masculina e eu, acho que poucos estavam aqui, a mesa de abertura do Seminário de ontem era predominantemente masculina, mesmo em uma universidade. Aqui é exceção, não sei se alguém fez a contabilidade, mas a Sílvia como é muito cuidadosa cuidou que pelo menos os componentes, os entrevistadores fossem 2 a 2, para garantir os 50\% (risos). Devia ter posto um casal aqui, para também ajudar a compor as perguntas...

Carneiro: Professor Chassot, vou continuar com a provocação.

Chassot: Eu perguntei para o Carneiro se ele não vinha vestido de Dominicano, inquisidor (risos).

Carneiro: Não, não... eu vou continuar com a provocação porque eu não gostei da sua resposta inicial (risos). A minha pergunta é a seguinte: a sua conhecida e reconhecida intensa produção literária o satisfaz ou o satisfez quando lançou? Eu posso considerá-lo, por exemplo, um Érico Veríssimo de direitos autorais? E fechando a pergunta, o senhor vive, sobrevive com algum de seus direitos autorais?

Chassot: De jeito nenhum! Não sai nem o leite para as crianças (risos)! O Alfabetização Científica, que é um dos meus livros mais vendidos, os direitos autorais de todas as edições são do MST. Quando eu escrevi o livro, vi que a maioria das coisas que eu tinha escrito ali dentro eu tinha aprendido com o MST. Então, achei que eu não podia botar meu nome na capa e ganhar dinheiro em

5 A encíclica, intitulada Laudato Si (Louvado Seja), de 190 páginas, é considerada histórica por ser a primeira vez em que um papa aborda, entre outros temas, aspectos relativos à preservação ambiental. 
cima disso. Agora, no mais, falar em Érico Veríssimo, você está brincando, eu queria ser Paulo Coelho, então! (Risos).

Carneiro: Então diga duas coisas, primeiro: qual livro seu, desses que são vendidos, que vem alguma coisa para o seu bolso? E qual o livro mais vendido?

Chassot: $\mathrm{O}$ "Ciência através dos tempos" é o livro mais vendido. Eu ganho 10\% no livro, então tu podes imaginar que o livro custa 50 reais eu ganho 0,50 centavos em cada livro... (aqui um lapso matemático, na verdade seriam 5 reais em cada livro).

Carneiro: Já vendeu 100 mil livros desse?

Chassot: Não, não chegou a 100 mil livros, ainda não...

Carneiro: A pergunta não é brincadeira...

Chassot: Ele é fiscal do imposto de renda? (Risos).

Carneiro: E nem provocativa. E para encerrar esta pergunta, o Caetano Veloso disse certa vez que depois que ele lança o disco ele não quer mais saber dele, não quer ouvir em nenhuma circunstância. Isso ocorre com o senhor em relação aos seus livros?

Chassot: Eu preparei agora uma reedição do "Ciência é masculina", 8a edição e eu modifiquei bastante coisa, reescrevi bastante coisa, atualizei, eu gosto de mexer nos livros antigos. Eu me chateio de ler muitas coisas assim, as minhas coisas, chega uma época que canso de ler a mesma coisa, mas, de vez em quando, eu reescrevo. Eu tenho muito retorno dos leitores, aliás, já que tu me fazes perguntas provocativas, eu também tenho que compensar. A melhor coisa dos meus leitores é a seguinte: professor, estou lendo o seu livro, ou li o seu livro, parece que eu estou the ouvindo, o senhor escreve como fala, isso é uma coisa muito grata, isso é muito bom para o autor. E é claro, outras coisas chegam. Eu uma vez estive em um estado aqui vizinho de vocês e a pessoa chegou 
com uma edição xerocada do livro para pedir o autógrafo (risos) e eu dei o autógrafo. Então, eu achei uma coisa muito bonita da pessoa, uma coisa muito humilde da pessoa.

Sílvia: Sobre o autógrafo na cópia xerocada, nós temos uma artista paraense chamada Wlad Lima que diz que sucesso é ter o CD pirateado e vendido no Ver-o-Peso (risos), porque ninguém pirateia uma coisa que não vende! Então, sinta-se também honrado em ter dado o autógrafo.

Chassot: Você já teve uma ideia roubada? Se a resposta é não é porque não teve nenhuma ideia boa (risos).

Sílvia: Então, essa apropriação indevida é sinônimo de sucesso. No mesmo rol das provocações do Carneiro, o senhor tentou escapulir da minha pergunta inicial, mas eu vou retomála com uma pergunta da plateia, incrementando um pouco. Considerando que vivemos em um "século doente", como o senhor mesmo disse, quais são os maiores desafios do professor de ciências nesse século? E eu acrescentaria, a velocidade com que o conhecimento é produzido hoje é insuperável, não temos como nos manter atualizados em relação a produção do conhecimento, impossível isso. Eu, há dias relembrava uma analogia feita pelo professor Leopoldo de $\mathrm{Meis}^{6}$, na qual ele mostrava que no século XVIII ou XIX você se atualizaria de todos os conhecimentos produzidos em todas as áreas de conhecimento se você passasse 4 meses lendo. Em seguida ele mostra já na contemporaneidade uma pilha de produção bibliográfica somente da fatia que ele pesquisa, que vai até o teto, que era a produção de um único mês. Nesse mundo doente, nesse mundo de aceleração, a gente está

6 Foi médico, pesquisador e professor titular do Instituto de Bioquímica Médica (IBqM) da Universidade Federal do Rio de Janeiro. 
sempre preocupado em incluir a novidade no currículo escolar. Como é que se inclui em geral uma novidade nos currículos? Acrescenta-se disciplina, e nos vivemos uma paranoia hoje. Acrescenta a história da ciência e uma série de coisas, e daqui a pouco é impossível alguém se formar num determinado tempo porque o conhecimento não para. Então o que, nesse mundo doente, transitório, móvel, fica de permanente para a gente ensinar em termos científicos?

Chassot: Primeiro Sílvia, em relação ao que tu disseste, hoje nós vivemos numa fase de engorda Lattes. Ou engoda Lattes, tirando o " $\mathrm{r}$ ". O que nós estamos fazendo para engordar o Lattes é fantástico! As pessoas vão ao congresso, apresentam o trabalho, mas eles não ouvem a conferência inaugural, nem a segunda conferência. Eles apresentaram os trabalhos e vão embora. Quer dizer, isso é só para aumentar o Lattes. Agora, o que é que fica de tudo isso? Aliás, tu és escritora também, eu acho que hoje se escreve muito e se lê pouco. As revistas científicas, a maioria delas, eu não acredito que as pessoas leiam. Eu sempre me lembro do caso Sokal de 19947. [Ainda sobre engordar o Lattes], outro dia um colega nosso me deu um livro - uma pessoa que eu prezo muito - que tem 20 artigos e ele é coautor nos 20 artigos. Ele reuniu e cada um publicou, quer dizer, ele tem 20 artigos no Lattes. Quem é que vai concorrer com um cara desses? Ele ganha sempre, de todos! Então, é demais essa mensuração, e eu acho que isso transforma

7 O caso Sokal (ou escândalo Sokal) foi um fato ocorrido no meio acadêmico na segunda metade da década de 1990. O caso veio à tona quando Alan Sokal, professor de física da Universidade de Nova Iorque, anunciou que teve aceitado um artigo-cilada para publicação na revista Social Text. Uma revista filiada às correntes teóricas ditas pós-modernas. Mais detalhe sobre o caso pode ser lido no livro "Alfabetização Científica", do próprio entrevistado, publicado pela editora UNIJUÍ. 
aquilo que se explica, o que se publica muitas vezes é uma bobagem, não tem sentido nenhum o que está se fazendo. As coisas não são muito sérias nessa área de publicação. Não sei se respondi...

Silvia: A primeira parte, a segunda é o que nos resta, o que fica de minimamente estável em ensino, na educação em ciências com essa aceleração da produção de conhecimento e nesse mundo que não para também de adoecer.

Chassot: $\mathrm{O}$ mundo não para de adoecer, todos somos testemunhas. Aqui nessa sala não tem ninguém que conhecia, há 15 anos, talvez há 12 anos, a palavra crack. Hoje sabemos o que é na escola. Essa é uma coisa dolorosa. Nós não conhecíamos esse ritmo acelerado de gravidez precoce também, agora isso não é a tua pergunta. Mas é tanta coisa que nós não nos damos conta de tudo que temos que ler na nossa área, e aí eu acho que talvez tenhamos que pensar em ser seletivo naquilo que lemos, e naquilo que escrevemos, e aí não vamos encontrar editores nem consumidores para as coisas que escrevemos. A aceleração é tão grande e há modificações significativas em todas as áreas que não sabemos como é que vamos fazer tudo isso, mas são os desafios. É aquilo que se soubéssemos, se tivéssemos certeza não precisávamos trabalhar sobre isso. E talvez seja como área de pesquisa e investigação.

Silvia: Qual é a sua aposta?

Chassot: Eu aposto que vamos dar conta. Agora como, não sei! Mas, eu acho que vamos dar conta, porque somos capazes de encontrar coisas novas.

Licurgo: Professor, gostei da menção que você fez ao fato de encontrar os leitores dos seus livros. De dizer que quando leem percebem que é como se estivessem falando com o senhor. Eu não sabia também, até alguns anos atrás, pode-se dizer 20 ou 15 anos, 
o que era alfabetização científica e eu fui aprender no seu livro. Encontrei em uma livraria - num evento - dessas que colocam nas portas dos eventos que a gente vai com frequência, olha, "que diabos é isso? Alfabetização científica?" Nunca tinha ouvido falar, ainda mais, como foi dito aqui pela professora Silvia, a minha área de pertencimento primeiro é a Geofísica, então essa literatura não fazia muito sentido circular por lá. Bem, li, gostei muito do livro, uma leitura fácil e agradável, venho recomendando a leitura e etc., mas, com o passar do tempo eu conheci uma outra alfabetização científica, um outro livro de alfabetização científica escrito por um francês. E aí eu vejo essa história da impermanência que é o nosso tema aqui. Os saberes não permanecem nos lugares, aí eu vejo que a educação científica apareceu para mim no Brasil, caiu em minhas mãos por sua influência, depois eu encontro lá na França, e depois eu tenho a Scientific Literacy que também circula nos Estados Unidos, na Inglaterra, no Canadá. Então esse conceito, essa ideia não permanece. Com a sua vivência, como é que o senhor vê essa proliferação de ideias e de conceitos, às vezes semelhantes, às vezes idênticos, como é que podemos lidar com isso? Precisa ter tanta caracterização minuciosa sobre sutilezas, diferenças conceituais tais como: "não, letramento é isso, alfabetização é aquilo" e quando você vai ver as diferenças são pequenas, na verdade são semelhantes, não é? Como é que o senhor vê essa impermanência geográfica, não se permanece em um mesmo lugar, essa impermanência conceitual, conceito surge e depois não permanece como ele foi gerado, como é que a gente pode lidar com isso nesse momento de impermanências?

Chassot: Bom, em primeiro lugar eu acho que temos que dar conta, da marca do século XXI em termos de impermanência, que são as migrações. Hoje temos 30 milhões de imigrantes andando 
por aí, e destes mais da metade são crianças. Isso é doloroso. Isso é muito doloroso. Nós estamos longe disto, não sabemos o que está acontecendo com esses movimentos migratórios. E tu fala da impermanência geográfica. Bom, a da ciência e acadêmica, o "Alfabetização Científica" foi publicado no ano 2000 a primeira edição, portanto tens direito de falar com propriedade de todas as outras coisas que surgiram depois dele e melhor do que ele. Eu queria chamar a atenção para o título do meu último livro que saiu em novembro de 2016. "Das disciplinas à indisciplina" e esse título provocador, eu vou contar como surgiu, eu nem sei se eu já contei em algum lugar, mas já fiz. Em 2015 fui convidado para fazer uma palestra no Congresso Brasileiro de Química que se reunia em Goiânia naquele ano. Rapidamente uma nota de rodapé tem que distinguir: no Brasil nós temos duas sociedades científicas ligadas à Química, uma Sociedade Brasileira de Química, que é mais acadêmica, e a Associação Brasileira de Química que é mais ligada à indústria, e foi a Associação Brasileira de Química, como nós brincamos, os nossos irmãos separados da $\mathrm{ABQ}$, que promovia o congresso em Goiânia. E eu nesse congresso tive a audácia de dizer que química não existe. Imagina tu ires à um congresso de química e chegar lá e dizer que química não existe. E eu acho que não existe química, não existe biologia, não existe geografia, não existe física. Existe ciência. Eu acho que cada vez mais temos que ir para essa indisciplinaridade. A indisciplinaridade é a radical negação da disciplina. E aí é preciso lembrar o conceito etimológico de disciplina. Disciplina era o 'chicote no rego' que as ordens religiosas usavam para se disciplinarem. "Irmã, já fizestes a tua disciplina hoje? Irmão, já fizestes a tua disciplina hoje? De tantos açoites?". Eu me lembro bem da minha escola, na segunda parte do ensino fundamental, que era o ginásio, uma escola Marista. 
Em toda parte tinha a plaquinha: "Deus me vê!" Imagina a placa "Deus me vê" no banheiro? (Risos). Claro que tem uma versão pós-moderna do "Deus me vê" que é "Sorria, você está sendo filmado", em toda parte. Engraçado, pergunta no hotel se tu podes deixar notebook no quarto, eles dizem: "Sim, nós temos câmeras em todas as dependências". Aí eu tenho que me comportar direitinho de noite também (risos). Mas eu acho que temos que negar a disciplina nesse sentido etimológico. Alguém vai me dizer que tem alguma coisa que a física é diferente da química na sua metodologia. Sim, é claro que sim, mas eu não sei dar um exemplo, nenhum, e desafio, gostaria que alguém nessa sala que soubesse me dizer, um exemplo que fosse coisa só de química ou só de física. Hoje tu vais ao médico e diz: "Doutor eu estou com um problema aqui no ouvido". O médico te olha, te examina, pede exames e diz: "Olha, realmente tu tens um problema no ouvido direito, eu vou te encaminhar para um colega meu porque eu só trabalho com ouvido esquerdo". Então, é mais ou menos a mesma coisa que nós fazemos na ciência. E nós temos que fazer um esforço de ir para essa indisciplinaridade. E essa indisciplinaridade, esse "in" primeiro, entrar dentro das outras, você tem que entrar. Eu que sei um pouco mais de química, tenho que entrar dentro da física, da biologia, da matemática, da história, da geografia, da filosofia, das ciências sociais. $O$ segundo movimento é trazer as outras disciplinas para nós. Eu não consigo ensinar química sem saber física, sem saber biologia, sem saber matemática. E o terceiro é essa negação da disciplina, que eu já disse nos seus aspectos etimológicos. Talvez essa seja a grande solução, temos uma ciência. Hoje alguém me disse assim quando eu comentei sobre uma professora da UFPA: "sim, mas ela é da matemática, nós somos das ciências", como se a matemática não fosse uma ciência também. Aliás, na 
placa está bem claro isso, "Educação Científica e Matemática”, eu colocaria só Educação Científica. Mas, isso é uma desculpa que os epistemólogos não vão me permitir agora. Mas, eu acho que podíamos ir, tem que conseguir pensar, as Ciências Sociais e as Ciências Humanas como um todo. É claro que cada uma delas tem uma disciplinarização, e é claro que eu sou a favor da especialização, por exemplo, na medicina, se eu tiver um problema de joelho eu preciso de um médico especialista, eu não vou querer um generalista. Mas, precisamos também do generalista e no ensino de ciências precisamos de professores generalistas, daqueles que saibam trabalhar o conhecimento maior do que saber um pouco de uma parte específica da física, da química, ou da biologia. Eu acho que é isso.

Licurgo: $\mathrm{O}$ senhor mencionou que muito do que tem no livro "Alfabetização Científica" foi inspirado no que o senhor vivenciou no MST. Uma informação interessante, valorosa. Aí eu lhe pergunto, em outras bibliografias, você teve inspiração dos saberes da alfabetização científica vindos da América do Norte, da Europa, ou de outro lugar do planeta?

Chassot: Não, mas apenas daqueles..., como eu vivo num dos estados que tem maior influência da colonização europeia, principalmente alemã, italiana e polonesa, eu acho que eu aprendi muita coisa nessa ascendência. Eu li alguma coisa, mas não conheço, eu não sei isso.

Cely: Confesso para vocês que eu gosto muito de ler as dedicatórias dos livros, teses e dissertações.

Chassot: Professora, eu disse a mesma coisa outra hora...

Cely: Acho ótimo, eu adoro ler dedicatórias, agradecimentos, acho que se eu pudesse um dia escrever algo científico sobre isso, é muito interessante, porque lendo dedicatórias e agradecimentos 
a gente fica sabendo muito da vida da pessoa, se é casado, se é separado, quem é a esposa, se tem filhos, se tem netos, onde trabalha, onde mora, não é? Se é homossexual, se tem cachorro ou não. Outro dia eu li uma tese e a autora dedicou, os 5 ou 6 anos na reclusão de escrita da tese, ao seu cachorro de estimação porque foi companheiro fiel (risos). Havia um total silêncio ao orientador, mas não ao cachorro que foi fiel até o último momento. Então professor, lendo alguns agradecimentos e dedicatórias que o senhor fez nos seus livros, tem uma expressão que muito me chamou atenção, dedicando às suas netas, a expressão "afortunadamente viveriam novos tempos, mas não necessariamente melhores tempos”. E aí vai a minha pergunta para todos nós, se nesses tempos que vivemos, essa atualidade, se esses novos tempos são melhores tempos (?) e se a ciência contribuiu ou não para que a gente pudesse chegar ao padrão civilizatório menos tumultuoso, como nós vivemos no Brasil e no mundo?

Chassot: Professora, primeiro tenho que dizer à senhora que eu também gosto muito de ler os agradecimentos. Recebo muita tese e dissertação para avaliar e a primeira coisa que leio são os agradecimentos. Eu me divirto, como a senhora. Mas tem um tipo de agradecimento que me atrapalha, eu tenho vontade de não ler o trabalho e devolver "Eu agradeço à Deus que inspirou esse trabalho”. Quem escreve que Deus inspirou o trabalho, Deus nunca vai inspirar uma coisa errada! (Risos). Tem que ser um trabalho perfeito, claro! Quem é que inspirou Maomé a escrever o Alcorão? Maomé entrava em transe, o Arcanjo Gabriel ditava para ele, mas Maomé era analfabeto, então ele se reunia com os escribas e disse: "olha, o anjo me disse isso, e isso, e isso..." e aí isso levou um processo de mais de 10 anos fazendo isso. E hoje quem ousar dizer uma coisa errada que está no Alcorão... Então, se eu recebo uma 
tese inspirada por Deus não vou encontrar nada, até o cara que escreve lá o sujeito e depois põe vírgula para indicar o predicado, se Deus que inspirou aquilo, está certo (risos). A respeito dos tempos, eu acho que nós vivemos em tempos melhores, mesmo que eu tenha dito que é um século doentio, nós vivemos que tempos melhores. Essas coisas que estamos falando aqui agora, jamais falaríamos, por exemplo, se tivessem aqui as nossas avós. Aliás, elas não estariam aqui, estariam cuidando dos filhos em casa, elas não viriam para a academia.

Cely: Elas estariam no supermercado... (alusão ao caso Marcela Temer).

Chassot: Eu acho que nossas avós não iam no supermercado... Mas, acho que vivemos em tempos melhores. $\mathrm{O}$ que é poder dizer, por exemplo, uma coisa tão simples como essa, quase me recuso ler uma tese inspirada por Deus, mesmo que não acredite. É um respeito ao cara. Quer dizer, podemos dizer essas coisas, podemos tratar dessas coisas, eu acho que vivemos novos tempos. Podemos ter mulheres que fazem coisas igual, tem a capacidade de trabalho igual, e ter mérito e receber igual aos outros, isso não veríamos tempos atrás, aliás ainda não cumprimos isso. Esses tempos são melhores. Lamentavelmente não sabemos conviver em um mundo que criamos e criamos também armas, bombas atômicas...). Elegemos um louco para ser presidente da maior nação, a mais poderosa do mundo. Então, temos essa situação que, às vezes, dá desesperança, mas acho que nossos netos viverão tempos melhores que nós.

Carneiro: Professor Chassot...

Chassot: Uma pergunta inspirada por Deus... (risos).

Carneiro: Minha primeira vocação/profissão foi jornalismo, do qual, vejam só, eu migrei para o magistério, imaginem os 
salários. Professor ganha mal e eu pulei do jornalismo para o magistério. Por isso eu continuo sendo jornalista por vocação, mas não por profissão. Eu sei que você é um leitor contumaz e voraz de jornais impressos, não é? Você já disse em livros, acabou de dizer aqui. Eu já vi em fotos você na piscina num dia de domingo, cercado de jornais. Eu li alguma vez no seu blog. E você já disse en passant alguma coisa, já falou a respeito. Mas, pergunto incisivamente: como você avaliaria o avanço da internet contra a mídia tradicional? Em todos os sentidos, seja na quebra da qualidade, seja na extensão do abalo econômico. Nem vou falar de livros agora, só vou tocar no jornal que é um dos seus assuntos favoritos também.

Chassot: Quando morreu o Papa Pio XI e foram avisar o arcebispo de Porto Alegre que o papa tinha morrido e tinha que bater o sino, ele perguntou: "o Correio do Povo já noticiou?" E aí disseram que não. "Então vamos esperar noticiar". A imprensa tinha crédito. Hoje, a internet que faz o papel da grande imprensa, divulga. Eu fico impressionado a quantidade de coisas que recebo de colegas ditos ilustrados e letrados e mandam coisas... Tenho uma dificuldade, quase não repasso mensagens, mas quando me repassam olho o remetente e tenho que dizer: "Fulano, o Zé me mandou isso? Mas ele não viu que é mentira? Bobagem?" Então hoje se divulga, e esses dias eu publiquei, não sei dizer agora, o número de mensagens que são geradas a cada segundo, são milhões e se espalha isso. Eu acho que se a intensão da imprensa, o invento de Gutemberg é considerado a maior descoberta do segundo milênio por alguns, a internet, realmente é a grande invenção da virada do segundo para o terceiro milênio. Agora de novo, aquela coisa que tu já ouviste eu dizer ou escrever, até água tomada em excesso mata por uma doença chamada afogamento, eu acho que estamos 
nos afogando na grande quantidade de notícias, e temos que ser críticos. Eu não acredito na maioria do que se publica, e vale hoje, lamentavelmente a mesma coisa para o jornal impresso. $\mathrm{O}$ jornal impresso tem uma vantagem sobre a internet, porque ele custa mais a sair, ele é um pouco mais crítico, ele demora um pouco. $\mathrm{Na}$ internet, as pessoas recebem e pá! Publicam coisas e mentem na internet.

Silvia: Eu vou tentar reunir duas questões que foram feitas aqui, me desculpem se não conseguir contemplar plenamente as duas, mas vou fazer uma síntese. As questões giram em torno de, se nós professores da academia não ocupamos o espaço na sala de aula, usando uma expressão que foi colocada aqui "no chão da escola”, outros vem e ocupam. Os apresentadores, que estão na televisão por aí a fora fazem o papel dos educadores que não estão na escola. E a outra diz respeito aos interesses que estão presentes na escola, que interferem na educação. Eu acho que as duas podem ser reunidas na ideia de que a educação está fugindo das mãos dos educadores.

Chassot: Eu acho que o jornalismo, particularmente o jornalismo radiofônico é o grande formador de opinião hoje. E eles fazem inclusive testes. Tem algumas pústulas no meu estado que ocupam espaços privilegiados do rádio, e eles ainda dizem assim: “vamos ver quantos estão me ouvindo, buzinem agora!” Então dá ou não um buzinaço na cidade porque estão ouvindo o cara. E esses caras se autodenominam, e também é justo esse nome que eles dizem, que são formadores de opinião. Eles formam opinião. E como é que eles formam opinião? Eles são coerentes acima de tudo, por que eles estão à serviço de seus empregadores. E os seus empregadores querem que se diga que os professores que estão em greve são uns vadios, querem que o MST que está fazendo 
ocupações, que digam que não são ocupações, são invasões. Então eles falam aquilo que os donos do poder querem. Então, isso a primeira parte da tua pergunta, a segunda parte, como é que nós perdemos o nosso lugar? Nós perdemos o nosso lugar, eu acho que pela omissão. Por sairmos, para deixarmos os outros pegarem os nossos lugares. Eu acho que nós temos que fazer, sermos contra, eu acho que aqui nessa sala provavelmente todos são contra, àquela proposta da escola sem partido. Por que essa escola sem partido não existe, não pode existir, será uma escola vazia, o quê que vai se ensinar? Eu acho que a escola hoje tem sim uma função política, e essa função política é verdade nós vamos ver como é que ela vai ser exercida. Eu não estou falando de função política partidária, mas uma função política de mostrar as injustiças sociais. Eu acho que a escola que não denunciar, os professores que não denunciarem as injustiças que ocorrem estão sendo omissos, e isso faz parte de ensinar ciências, de ensinar religião, ou de se ensinar seja lá o que for. Temos que denunciar, não só anunciar.

Licurgo: Professor Chassot, eu li alguns fragmentos de um livro, que infelizmente ainda não consegui pegar para ler todo chamado "A alegria na escola", de Jorge Snyders, não sei se você conhece, da década de 1980.

Chassot: Sim, o autor eu conheço, o livro não.

Licurgo: Pelo pouco que li, pela leitura indireta que fiz, ele defende que a escola deve ser um espaço para se aprender com alegria. E curiosamente, e contraditoriamente, dividi uma disciplina numa certa ocasião com um colega, e esse colega professor manifestou-se para turma dizendo o seguinte: "olha, não tem alegria nenhuma em aprender. Para aprendermos temos que nos sacrificar. E o sacrifício não é alegre, então vamos acabar com essa história que tem alegria em aprender”. Aquilo me chamou 
muito a atenção porque não fazia muito tempo que eu tinha lido alguma coisa sobre alegria na escola. Fiquei pensando, bem, ele traz alguns argumentos de um esforço para a aprendizagem que é na verdade a mensagem que ele quer trazer. E num certo sentido tem alguma coerência. Mas eu não posso acreditar 100\% nisso, porque quando me pego aprendendo eu tenho uma alegria enorme. Então, aprendi com você e isso é legal, eu sinto um prazer e acredito que não estou só, pelo menos falando aqui neste auditório eu acho que muitos de nós temos a mesma sensação. Mas, me chamou a atenção, esta fala do colega professor, e que tinha também uma coerência interna, embora não concorde, que eu deveria respeitar. Lhe pergunto: Nesses seus 56 anos de magistério, é com alegria ou sem alegria que se aprende na escola?

Chassot: Duas coisas, primeiro, não sei há quanto tempo já estamos aqui hoje nesta tarde, mas acho que já estamos quase 15 ou 20 minutos (risos).

Silvia: Quase 2 horas!

Chassot: Quero dizer que aprendi muita coisa hoje à tarde, eu estou levando lição de casa para fazer, muitas. Acho que ninguém suou sangue, ninguém chorou, nós até rimos, e eu acho que rir é bom. Nos divertimos! Foi um convescote alegre, esse! E um convescote aprendizagem, portanto tem a teoria nisso. A segunda coisa eu tenho que contar, e não fazer uma correção nesse vídeo de apresentação, eu, há exatamente um ano fui demitido da única instituição que eu tinha ainda vínculo de aula na graduação, o Instituto Metodista e o argumento para a minha demissão era que eu viajava demais, eu estava pouco na instituição, mesmo que nunca tivesse faltado aula, nem chegado atrasado em nenhuma. Atualmente não estou em nenhuma sala formal de graduação. Só estou trabalhando na pós-graduação, na REAMEC. Então eu 
tenho muitas saudades, esses dias eu fui à uma banca nessa mesma instituição e eu disse assim: "Vir aqui me dá dois tipos de sensação, uma de sabor e outra de dessabor. Sabor quando eu sempre sou tão bem acolhido pelos meus colegas, homenageado, querido bem. E dissabor por que eu sempre recordo que há um ano eu fui demitido daqui, e tinha uma psiquiatra na mesa e a professora Luciane sabe que eu ainda não consegui elaborar esse luto da demissão. Eu tenho saudade da sala de aula. Se vocês souberem uma escola que precisem aí de dar aula (risos) e puder me avisar, eu estou disponível. As pessoas acham que a gente ganha muito dinheiro viajando, dando palestra e coisas, mas eu não sei, e nosso fiscal do imposto de renda já está me olhando (risos), mas acho que temos na maioria das vezes prejuízo. Hoje em dia a gente vem pelo prato de comida e nem paga um táxi. Então, eu gosto disso. A minha mulher, quando querem que eu tire uma fotografia ele diz assim: "Pensa que tu está dando uma palestra!" (Risos). Licurgo, eu acho que vale à pena ter alegria para aprender. Vale à pena dar aula.

Cely: Eu também gostaria de agradecer à Sílvia, essa oportunidade, é sempre com muito gosto que eu retorno à esta casa, que eu sempre sou muito bem acolhida. Rever amigos, colegas e essa jovialidade científica, na perspectiva de fazer um mundo cada vez melhor. Eu também gostaria de agradecer ao professor Chassot essa oportunidade, é sempre muito bom para mim, e acho também que para todos nós revê-lo, ouvir, aprender, sempre de forma prazerosa. Já faz um bom tempo que eu não moro aqui em Belém, então à época que eu ainda morava sempre a Sílvia me avisava "O professor Chassot vem aí", e eu vinha, não só aprender, mas sobretudo aprender rindo. Eu acho que a alegria desses encontros influencia muito a nossa formação como pessoa e como 
investigadores. Eu gostaria de encerrar professor, perguntando eu e minhas curiosidades... Quando leio um trabalho sempre fico me pergunto: "mas porque aquele autor se prevaleceu desta expressão, desta palavra, porque essa letra é maiúscula, e essa é minúscula, porque grafa assim”. Quando a gente lê a gente lê também o desenho gráfico do texto. E eu queria saber professor, porque em muitos de seus trabalhos, a sua ciência é com letra maiúscula. Eu fiquei a me perguntar, essa ciência que é masculina, essa ciência que grande parte, pelo menos nos últimos tempos aliada ao capital, essa ciência que tem um lado, de qual lado dessa ciência nós estamos juntos com essa ciência que tem lado... E eu queria saber professor, por que que sua ciência é grafada com letra maiúscula, e de que lado é a sua ciência, ou de que lado o senhor está nesse trabalho como cientista também? Obrigada a todos.

Chassot: Tem um escritor português que a senhora deve conhecer se não me engano nascido na África, ele tem um sobrenome lindíssimo, Mãe.

\section{Sílvia: Valter Hugo.}

Chassot: Valter Hugo Mãe, pelo sobrenome Mãe eu acho lindíssimo. E ele escreve todos os seus textos em letras minúsculas. E ele explicou - eu o assisti falar no "Fronteiras do Pensamento", no ano retrasado - assim: "quem lê não diz assim Roda está escrito maiúsculo, da está escrito minúsculo, Ciência está escrito maiúsculo”. Nós lemos tudo, para ele não faz diferença. Não sei, eu acho que eu escrevi Ciência em maiúsculo como uma certa reverência. Eu já aprendi que quem escreve em inglês, quando escreve o

8 Projeto que propõe uma profunda análise da contemporaneidade e das perspectivas para o futuro. Comprometido com a liberdade de expressão, a diversidade de ideias e a educação de alta qualidade, o projeto promove conferências internacionais e desenvolve conteúdos múltiplos com pensadores, artistas, cientistas e líderes em seus campos de atuação. (Transcrito da página oficial: http://www.fronteiras.com/o-projeto- do projeto). 
pronome pessoal da primeira pessoa, $e u$, mostra um certo sinal de humildade em se escrever aquele $i$ minúsculo, então o meu corretor mesmo sempre corrige os meus is minúsculo para is maiúsculos. Eu acho bonito. Na minha assinatura o Ático e o Chassot eu sempre escrevo minúsculo. E ciência eu acho uma reverência. Meu nome não merece uma reverência, mas ciência merece, por isso que eu escrevo maiúscula (risos). E eu não sei se ciência tem lado, mas se tiver eu estou do lado da ciência que quer fazer o bem. Eu uma vez dizia que ciência parecia uma fada benfazejo de uma bruxa malvada. Eu não digo mais isso, nunca. Já me arrependi de ter dito isso por que soube que as bruxas são invenção dos homens todas as vezes que as mulheres estão criando, com direito, asas. Então não digo mais. Depois eu dizia que era uma bruxa e era um ogro. Também não digo mais. Hoje eu gosto muito daquela a ciência vista como o Golem, aquele ser da mitologia judaica que é a força poderosa, mas não sabe a força que tem. Quer dizer, a ciência não é boa nem má, quem é bom ou mal são os homens e as mulheres que usam a ciência. E eu trago outra metáfora bem simples uma faca serve tanto para fazer o bem como para fazer o mal, agora quem usa a faca pode ser do bem ou do mal. Quer dizer, o lado da ciência é que nem a faca, pode cortar um pão, pode fazer uma cirurgia e pode matar. A ciência também pode fazer um pão e pode matar, depende de quem usa a ciência.

Silvia: Para encerrar professor, uma pergunta bem simples do seu universo de discussão acadêmica. O que é ser alfabetizado cientificamente hoje?

Chassot: Bom, essa pergunta dava para escrever um livro sobre ela, eu acho. E tu a rotulas de bem simples, és generosa Sílvia. Eu acho que ser alfabetizado cientificamente é por exemplo, saber que aquele trovão, aquele relâmpago que assustou os nossos antepassados e que para isso fizeram que ele criasse Deuses tem uma explicação. Posso até não saber explicar, se o raio cai ou se o raio sobe não 
é professor Licurgo. Posso até não saber explicar isso, mas saber que isso não é mágica. Eu me lembro quando se inaugurou uma vez a eletricidade numa cidade e aí disseram: "olha, vão ser ligados os motores da cidade tal, e um vilarejo a $15 \mathrm{~km}$ de distância ia pela primeira vez ter luz. Mas é tão longe, na hora que ligaram lá, quem é que trouxe tão ligeiro a eletricidade para cá?”. Então entender por exemplo quando eu aperto ali apaga a luz, ou quando eu ponho a mão na torneira a água sai. Se as pessoas começarem a entender essas coisas, se as pessoas começarem a entender que realmente os alimentos que eles comem, aquela multinacional que vende o refrigerante também vende a água mineral com bastante sódio para vender mais refrigerante. Ler os rótulos, o quê que tem nos alimentos, entender quando a Monsanto ${ }^{9}$ diz que OGM não é Organismo Geneticamente Modificado, mas organismo geneticamente melhorado, alguém vem dizer que isso é mentira, e dizer que a Monsanto põe veneno na mesa. E eu também quero agradecer. Para mim também é um privilégio. Eu vim por outras razões à universidade e eu como sempre faço (quando venho) escrevi para Sílvia e para o Geziel dizendo que vinha. Os dois muito receptivamente "então vamos fazer isso!?". Se eu topo, claro que eu topo. E vamos fazer uma segunda rodada.

Sílvia: Hoje nós nos banqueteamos com palavras, pensamentos, ideias. Alguns se banqueteiam com comida, mas nosso banquete maior é esse, eu acho que é isso que nos alimenta, é isso que nos mantém mobilizados para continuar nessa profissão. Agradeço a presença de todos. Esse evento foi inteiramente gravado, assim que estiver editado vamos colocá-lo à disposição do público em geral. Muito obrigada.

9 Empresa multinacional de agricultura e biotecnologia, sediada nos Estados Unidos da América do Norte, líder mundial na produção de alimentos geneticamente modificados. 
Cely Nunes cursou Pedagogia nas Faculdades Integradas do Colégio Moderno; mestrado e doutorado na Universidade Estadual de Campinas (Unicamp). É professora aposentada da Universidade do Estado do Pará (UEPA). Atuou entre os anos de 2009 e 2014 como pesquisadora e docente na Universidade de Lisboa. Desenvolve pesquisa na área de formação de professores e política educacional.

José Carneiro é Jornalista de profissão, graduado em Ciências Sociais pela UFPA, mestre em Ciências Políticas pela Unicamp, mais recentemente especializou-se em História e Sociedade e Comunicação: Imagem e Sociedade pela UFPA, instituição pela qual está aposentado. Contemporaneamente atua na produção e publicação de textos memorialísticos nos seguintes temas: cinema, política, Amazônia, sociedade e meio ambiente.

Licurgo Brito é licenciado em Ciências Naturais e Física. Doutor em Geofísica pela UFPA. Professor do Instituto de Ciências Exatas e Naturais e do Instituto de Educação Matemática e Científica da UFPA, nos quais é docente na graduação e na pós-graduação. Experiência em gestão acadêmica tanto em universidade, quanto na Secretaria de Educação do Estado do Pará, onde atuou por 5 anos. Dedica-se à pesquisa em Ensino de Ciências com ênfase na temática Ciência, Tecnologia e Sociedade (CTS), atuando principalmente no Ensino de Física com ênfase em temas regionais da Amazônia.

Sílvia Nogueira Chaves é Licenciada em Ciências Biológicas pela UFPA, mestre e doutora em Educação pela Unicamp. Coordena o Grupo de Estudos e Pesquisa "Cultura e Subjetividade na Educação em Ciências" (GEPECS) do Programa de Pós-graduação em Educação em Ciências e Matemáticas/ UFPA, no qual é docente. Desenvolve pesquisas no campo dos Estudos Culturais, Formação Docente, Políticas de Subjetivação e das Narrativas (Auto)biográficas, com base nas quais tem publicado artigos, livros e capítulos de livros. É editora da Revista ExperimentArt. 